\title{
The Realist Tradition in American Public Opinion
}

\author{
Daniel W. Drezner
}

\begin{abstract}
For more than half a century, realist scholars of international relations have maintained that their world view is inimical to the American public. For a variety of reasons - inchoate attitudes, national history, American exceptionalism—realists assert that the U.S. government pursues realist policies in spite and not because of public opinion. Indeed, most IR scholars share this "anti-realist assumption." To determine the empirical validity of the anti-realist assumption, this paper re-examines survey and experimental data on the mass public's attitudes towards foreign policy priorities and world views, the use of force, and foreign economic policy over the past three decades. The results suggest that, far from disliking realism, Americans are at least as comfortable with the logic of realpolitik as they are with liberal internationalism. The persistence of the anti-realist assumption might be due to an ironic fact: American elites are more predisposed towards liberal internationalism than the rest of the American public.
\end{abstract}

$\longrightarrow$ ealists believe that they are an endangered species in the United States. Despite its long-standing status as the dominant paradigm in international relations, realist scholars and policymakers assert that Americans do not like their theory at all. In The Tragedy of Great Power Politics, John Mearsheimer concludes that, "American political culture is deeply liberal and correspondingly hostile to realist ideas." ${ }^{1}$ Other realists have echoed this sentiment for the past sixty years. According to these scholars, realism is pessimistic about both the nature of man and the effect that anarchy exerts on world politics. In a realist world, states will compete for power regardless of their regime type, and neither international institutions nor global norms will ameliorate this drive for power. ${ }^{2}$ In such a Hobbesian world, realists recommend that the United States ruthlessly focus on its national interests while

Daniel W. Drezner is Associate Professor of International Politics at the Fletcher School of Law and Diplomacy, Tufts University (daniel.drezner@tufts.edu).Previous versions of this paper were presented at the 2007 International Studies Association meeting in Chicago, IL, and at Yale University's Institution for Social and Policy Studies. He is grateful to Bethany Albertson, John Brehm, Joshua Busby, Jon Caverley, Richard Eichenberg, Benjamin Fordham, Nikolas Gvosdev, Don Green, Jacob Hacker, Lawrence Kaplan, Andrew Moravcsik, John Mearsheimer, Gideon Rose, Bruce Russett, Gregory Sanders, Stephen Teles, and John Schuessler for their comments and suggestions. Luisa Melo performed valuable research assistance, and the German Marshall Fund of the United States provided generous support during the drafting of this paper. abstaining from moral or ideological crusades designed to make the world more like America. This is fundamentally at odds with the more optimistic tropes inherent in liberal internationalism. Liberals would argue that multilateral regimes, democratic institutions, and economic interdependence can ameliorate the effects of anarchy. In such a Lockean world, the export of American values and norms advances American interests by getting others to want what Americans want. ${ }^{3}$

Realists and non-realists alike accept Louis Hartz's supposition that the Lockean worldview has an ideological chokehold over the American body politic. ${ }^{4}$ What I label the anti-realist assumption serves many useful purposes for the realist paradigm. If the American public dislikes realism, then U.S. foreign policy outputs represent a tough test of the theory. Any government in a liberal democracy wants to stay in office, so it should be reluctant to pursue a foreign policy at odds with the broad mass of its country's population. If successive U.S. governments pursued realist policies despite a hostile public, it would be robust evidence that the anarchic world system imposes a powerful structural constraint upon the foreign policies of states. The assumption also helps realists explain away movements in American foreign policy—such as Wilsonianism and neoconservativism - that appear to contradict the realist paradigm. They are explained as moments when America's creedal passions overwhelmed the principles of realpolitik. ${ }^{5}$

Despite the prevalence of the anti-realist assumption within international relations theory, there has been no systematic attempt to ascertain whether it is true. In part, this is because IR theorists and public opinion analysts often talk past each other. For decades, international relations 
theorists have focused on systemic-level explanations, marginalizing analysis of public opinion. At the same time, public opinion researchers, when they talk about American foreign policy, do not test whether the mass public adheres to foreign policy views consistent with one theoretical paradigm or another. Instead, they decompose the mass public into identifiable subgroups, in order to isolate individual-level determinants of foreign policy attitudes.

This article takes a critical look at the anti-realist assumption. I do so by reviewing the existing survey data and empirical literature on American public opinion towards foreign policy priorities and worldviews, military statecraft, and foreign economic policy for the past three decades. The results suggest that Americans are far more receptive to realpolitik than is commonly assumed. For the key components of U.S. foreign policy-war, trade, and grand strategy — realist tenets resonate just as strongly with Americans as liberal internationalism. When asked to weigh the costs and benefits of different foreign policy approaches, realism scores much better among the broad mass of Americans than realists tend to believe. At a minimum, the claim that Americans hold attitudes antithetical to realism is wrong. This might be because American indifference and rational ignorance of foreign policy problems creates a kind of "folk realist" attitude to coping with the rest of the world. Intriguingly, it is possible that realism resonates better with the mass public than it does with the elite public.

If the preliminary findings of this article hold up, there are important implications for both international relations theory and foreign policy analysis. At a minimum, the finding vitiates the premise that American foreign policy represents a "tough test" for realist theory. The underlying cause of American realist actions could emanate from domestic attitudes rather than the structure of the international system. For foreign policy analysis, the implications are equally fascinating. Since the heyday of George Kennan, the standard mantra about American foreign policy has been that a coterie of sober statesmen must manage international relations while holding back the primal impulses of an American public imbued with the "legalisticmoralistic" spirit. It could very well be that the situation is reversed-elite public opinion embraces the liberal internationalist ethos more readily than the broad mass of Americans.

The rest of this article is divided into eight sections. The next section demonstrates the breadth and depth of the anti-realist assumption in scholarly and public discourse. The third section parses out how this assumption could be falsified. The fourth section reviews the survey and experimental data and on American foreign policy worldviews and priorities. This review demonstrates mass support for the core tenets of realist thought. The fifth and sixth sections look at American attitudes towards the use of force and foreign economic policy, respectively. It finds that Americans are comfortable with realist uses of force and a relative gains approach to the global economy. The seventh section considers methodological counterarguments that could undercut the argument presented here. The final section speculates on the sources for the realist fallacy. One possibility is that realists are not reacting to the hostility of most Americans to realism, but to the hostility of American elites.

\section{The Anti-Realist Assumption}

Realism has a long and distinguished intellectual lineage, which is another way of saying that there are many varieties of realisms: classical realism, neoclassical realism, postclassical realism, offensive realism, defensive realism, structural neorealism, etc. ${ }^{6}$ Realists share at least one common belief, however-Americans do not like their policy wares. Sixty years ago, classical realists grounded this assumption on two arguments. The first concern, which stretches back to Thucydides, was that democracies had a disadvantage in crafting foreign policy vis-à-vis authoritarian governments because of the need to appease a mass public that holds inchoate views about international relations. ${ }^{7}$ While this concern applies to all democratic publics, the United States has been considered an exemplar of this problem. Indeed, elite wariness of mass American attitudes towards foreign policy has been around since the days of Walter Lippmann. In The Public Philosophy he warned, "The unhappy truth is that the prevailing public opinion has been destructively wrong at the critical junctures. The people have imposed a veto upon the judgments of informed and responsible officials." 8

The first wave of American public opinion research led to the Almond-Lippmann consensus, which suggested that mass attitudes towards foreign policy were inconstant, irrational, and ill-considered. ${ }^{9}$ Because the mass public was so uninformed about foreign affairs, scholars argued that their reaction to current events would be based on emotion rather than reason. This leads to a public with erratic mood swings about foreign policy issues of the day. A recent variation of this concern can be seen in debates about the "CNN effect." 10 In 1993, George Kennan described this effect as the tendency for American foreign policy to be, "controlled by popular emotional impulses, and particularly ones provoked by the commercial television industry." 11

The second concern was that Americans filter foreign policy decisions through a moralistic system of beliefs. This renders the mass public unable to digest the realist logic of a dispassionate, hard-headed national interest. ${ }^{12}$ Hans Morgenthau wrote that "the statesman must think in terms of the national interest, conceived as power among other powers. The popular mind, unaware of the fine distinctions of the statesman's thinking, reasons more often than not in the simple moralistic and legalistic terms of 
absolute good and absolute evil." 13 George Kennan warned that the "legalistic-moralistic approach to international problems" would resonate among the mass public. ${ }^{14}$ Henry Kissinger concludes, with more than a tinge of regret, that "it is above all to the drumbeat of Wilsonian idealism that American foreign policy has marched since his watershed presidency, and continues to march to this day. ...Wilson's historic achievement lies in his recognition that Americans cannot sustain major international obligations that are not justified by their moral faith." 15

These concerns have not abated as realist thought has adopted a more scientific cast. ${ }^{16}$ If anything, the reverse has been true-realists now assert that American political development has made the country and its citizens uniquely unable to accept the tenets of realism. ${ }^{17}$ Stephen D. Krasner concluded that "U.S. policy after the Second World War must be understood in terms of ideology: leaders were driven by a vision of what the global order should be like. ... The vision itself was a manifestation of American liberalism." ${ }^{18}$ John Mearsheimer is even more outspoken about the incompatibility between realist theory and American public opinion. Although Mearsheimer argues that offensive realism can explain U.S. foreign policy outputs, the theory cuts against American beliefs:

Realism is a hard sell. Americans appear to have an especially intense antipathy towards balance-of-power thinking. . . .

Americans tend to be hostile to realism because it clashes with their basic values. Realism stands opposed to Americans' views of both themselves and the wider world. In particular, realism is at odds with the deep-seated sense of optimism and moralism that pervades much of American society. Liberalism, on the other hand, fits neatly with those values. ${ }^{19}$

Scholars argue that the exceptionalist history of the United States allowed a liberal worldview of international relations to develop unfettered by realpolitik concerns. Separated from Europe, the United States emerged as a great power relatively unscathed by foreign invasion, military occupation, or economic deprivation. There was no need for realism when no great power could overcome the stopping power of water. ${ }^{20}$ A liberal approach to foreign affairs was most symbiotic with the liberal tradition in domestic politics. ${ }^{21}$ Liberal internationalism is more ideationally consistent within America's self-image as "a shining city on a hill." Democracy promotion in particular is rooted in America's national identity and national security strategy. ${ }^{22}$ As George W. Bush phrased it in his second inaugural address:

From the day of our Founding, we have proclaimed that every man and woman on this earth has rights, and dignity, and matchless value, because they bear the image of the Maker of Heaven and earth. Across the generations we have proclaimed the imperative of self-government, because no one is fit to be a master, and no one deserves to be a slave. Advancing these ideals is the mission that created our Nation. ${ }^{23}$

Bush's rhetoric underscores the fact that realists are not the only analysts who make this assumption. Michael Lind argues the ideas of realpolitik fundamentally conflict with the "American School" of foreign policy. ${ }^{24}$ Walter Russell Mead argues that "continental realism" is ill-suited to the United States. ${ }^{25}$ Within the academy, liberal institutionalists, constructivists, and public opinion analysts have echoed this line of argument as well. ${ }^{26}$ Michael Doyle asserts that, "in the United States, and in other liberal states to a lesser degree, public policy derives its legitimacy from its concordance with liberal principles. Policies not rooted in liberal principles generally fail to sustain long term public support." ${ }^{27}$ Indeed, the norms variant of the democratic peace hypothesis is predicated on the idea that democratic publics hold different sets of values on foreign policy issues than realpolitik statesmen. More recently, neoconservatives have insisted that realism is antithetical to American values. Robert Kagan and William Kristol have argued, for example, that precisely because Americans do not think like power-maximizing realists, other states would not balance against the U.S. ${ }^{28}$

It should also be noted that the anti-realist assumption is not limited to the United States. Ironically, America's most recent foreign adversaries have also made this assumption. In the past decade alone, Slobodan Milosevic, Saddam Hussein, and Osama bin Laden all assumed that the American public was reluctant to apply force in a ruthless, realpolitik manner. They all assumed that the mass public was inordinately sensitive to casualties, and that this sensitivity would constrain American leaders. The anti-realist assumption led each of them to underestimate the likelihood of American military action. ${ }^{29}$

To be sure, this logic behind the anti-realist assumption is not universally accepted as a given. Numerous historians of American foreign policy have argued that multiple traditions have competed for dominance within American foreign policy, some of which are perfectly compatible with realism. ${ }^{30}$ It should also be noted that the anti-realist assumption does not mean that realists believe their model cannot explain U.S. foreign policy. ${ }^{31}$ Mearsheimer, for example, asserts that "we act according to the dictates of realpolitik, but we justify our policies in terms of liberal ideologies. So what is going on here is that in many cases, elites speak one language [in public], and act according to a different logic and speak a different language behind closed doors." ${ }^{32}$ At a minimum, however, there is a strong consensus across a broad spectrum of international relations theorists and public commentators: powerful ideological currents within American political development cause generations of Americans to repeatedly reject the logic of realpolitik.

\section{Testing the Assumption}

Realists share a consensus about how the structure of the international system works, but that consensus partially breaks down at the level of foreign policy recommendations. ${ }^{33}$ Realists debate amongst themselves the 
Table 1

Testable predictions about American preferences

\begin{tabular}{|c|c|c|}
\hline Issue area & Realist policy preferences & $\begin{array}{l}\text { Liberal internationalist } \\
\text { policy preferences }\end{array}$ \\
\hline $\begin{array}{l}\text { Foreign policy priorities } \\
\text { and world views }\end{array}$ & $\begin{array}{l}\text { - Pessimistic or Hobbesian } \\
\text { appraisal of international } \\
\text { environment } \\
\text { - Pursuit of national interest } \\
\text { - Homeland security and territorial } \\
\text { integrity come first } \\
\text { - Balance against rising powers }\end{array}$ & $\begin{array}{l}\text { - Cautiously optimistic or Lockean } \\
\text { appraisal of international } \\
\text { environment } \\
\text { - Pursuit of interest through } \\
\text { international law } \\
\text { - Promotion of democracy, human } \\
\text { rights } \\
\text { - Reliance on multilateral institutions } \\
\text { to regulate conflict and power in } \\
\text { world politics }\end{array}$ \\
\hline $\begin{array}{l}\text { Justification and support } \\
\text { for the use of force }\end{array}$ & $\begin{array}{l}\text { - Self-defense } \\
\text { - Violation of state sovereignty } \\
\text { - Containment of a rising power } \\
\text { - Tolerance of costs if the opponent } \\
\text { suffers more }\end{array}$ & $\begin{array}{l}\text { - Self-defense } \\
\text { - Humanitarian intervention } \\
\text { - Promotion of self-determination/ } \\
\text { democratic regime change } \\
\text { - Extreme sensitivity to costs of war }\end{array}$ \\
\hline Foreign economic policy & $\begin{array}{l}\text { - Emphasis on relative gains } \\
\text { - Suspicion of economic } \\
\text { interdependence leading to } \\
\text { vulnerability } \\
\text { - Hostility to foreign ownership of } \\
\text { strategic assets }\end{array}$ & $\begin{array}{l}\text { - Emphasis on absolute gains } \\
\text { - Support for economic } \\
\text { interdependence, liberalization } \\
\text { - Acceptance of foreign ownership }\end{array}$ \\
\hline
\end{tabular}

importance of balancing, the importance of maximizing power or security, and the optimal grand strategy for American foreign policy. ${ }^{34}$ Despite these conceptual disagreements, realists do share a core of policy recommendations that distinguishes them from other foreign policy paradigms. Realists stress that the anarchic world structure makes it impossible for governments to fully trust each other, forcing all states to be guided solely by national interest. Because all states can only count on their own resources and capabilities, realists are skeptical of the utility of international institutions to regulate world politics. Realists advise paying attention to relative gains when considering cooperation. The question, for realists, is not "will both of us gain?" but "who will gain more?" 35 The U.S. government should also be prepared to balance against rising great powers, before they amass sufficient power to become a peer competitor. ${ }^{36}$ This paradigm also has a large number of negative policy prescriptions. Realism is uninterested in the domestic politics of other countries, and recommends against interventions to promote democracy or human rights. Realists are wary that this kind of policy activism could drain scarce resources or trigger the security dilemma. ${ }^{37}$ They also caution against excessive economic interdependence, both because of relative gains concerns and fears of asymmetric vulnerability.

Table 1 lists the set of testable predictions that flow from the anti-realist assumption across three areas. The category of foreign policy priorities and worldviews considers how Americans views international politics, and how they would rank order particular objectives for the American government to achieve. To realists, the international system is a Hobbesian one, in which anarchy makes it impossible to fully trust other countries. The United States' top priority should therefore be the defense of American borders and territorial integrity. Alliances should be based on geopolitics and not regime type. The U.S. government should also be prepared to balance against rising great powers, before they amass sufficient power to become a peer competitor-again, regardless of regime type. Beyond those obligations, however, realists would not support other "internationalist" policy priorities-the protection of human rights, democracy promotion, or the strengthening of multilateral institutions.

The anti-realist assumption predicts that the American mass public should be more likely to trust other countries and prefer cooperation over self-help. They are therefore expected to place a greater reliance on international law and multilateral institutions to regulate world conflict. In terms of substantive preferences, Americans are predicted to advocate for the spread of liberal norms to other countries. The active promotion of democracy, human rights, and economic development to other countries cannot be defined as realist. ${ }^{38}$ Policies that contravene liberal values - alliances with unsavory regimes, or 
tolerance of human rights abuses to advance the national interest-should register significant opposition. Strong American support for liberal objectives would substantiate the anti-realist assumption.

Realists would also be expected to differ with the mass American public on the justification and use of force. For realists, again, the top priority would be preserving the territorial integrity, homeland security and regional hegemony of the United States. Because realists place great value on state sovereignty, they would be expected to support the use of force to deter or repel a violation of that sovereignty. Similarly, realists would support military measures to contain rising powers. When war breaks out, realists can tolerate a heavy loss of men and materialprovided the opponent suffers even greater costs.

The anti-realist assumption predicts that Americans would support the use of force for a much wider set of policy objectives, but not at a sustainable level. To ensure the spread of liberal norms in world politics Americans would be expected to support other types of military missions, such as humanitarian interventions, multilateral peacekeeping, and intervention in civil conflicts. It is safe to say that realists would disapprove of all of these activities. ${ }^{39}$ Despite the support for a broader category of military actions, however, Americans are also simultaneously hypothesized to be squeamish about the costs of prolonged military commitments. ${ }^{40}$ As Peter Feaver and Christopher Gelpi observe, "There is an implicit comparison between a naïve public and a 'hard-nosed' view of what it takes to be a great power (or the only superpower)." 41 Americans are expected to sour quickly on uses of force that entail significant costs in the form of mounting casualties - regardless of the outcome on the battlefield. Consistent with the Almond-Lippmann consensus, realists believe that Americans will prefer cutting and running if the use of force fails to achieve victory within a short time span.

Foreign economic policy is the final significant policy arena where realists and the mass public are expected to diverge. Realists should be warier of trade liberalization and economic interdependence than most Americans. In an anarchic world system, realists argue that states must be concerned about the distribution of gains that come from economic cooperation. ${ }^{42}$ Even if economic integration leads to a balanced distribution of gains, realists are wary of the interdependence that can emerge from a liberal economic order. For realists, "interdependence" is simply another word for "vulnerability," and implies a loss of economic autonomy and heightened interstate frictions. ${ }^{43}$

Because the United States is such a large economic power, the realist concern about interdependence should be relatively muted when thinking about trade with smaller countries. Relative gains concerns should be present, however, when thinking about economic exchange with other candidate great powers, such as China, Japan, and the Euro- pean Union. The fear of rising economic powers should be present regardless of regime type.

The American public is predicted to be more comfortable with an open economic order. Mainstream economists argue that free trade is a win-win proposition, benefiting all countries that participate. Because Americans are predicted to care more about absolute gains than relative gains, there should be majority support for any liberalizing measures, given that the economic benefits outweigh the costs. In a similar vein, the broad mass of Americans are expected to be more comfortable with enhanced levels of economic interdependence than realists-in part because of the longstanding liberal argument that interdependence is a force for peace. ${ }^{44}$

Two sources of polling data will be used to test the robustness of the anti-realist assumption. Extensive surveys have been conducted to test American attitudes towards the use of force, the expansion of trade, and the proper orientation of American foreign policy. The most prominent of these polls is the quadrennial Chicago Council on Global Affairs (CCGA) survey of public attitudes about American foreign policy. ${ }^{45}$ If the anti-realist assumption is correct, then one should see low levels of support for realist policies and greater levels of support for liberal policies in these surveys.

It should be stressed that these data are far from perfect. The most obvious problem is that most survey questions are not tailored to isolate whether Americans are receptive to any particular paradigm of international relations theory. Many of the survey questions that have been consistently asked do not directly address realist doctrine. Furthermore, on some foreign policy questions there is extreme sensitivity to the framing of the questions. Nevertheless, public responses to real-world policy problems can serve as useful proxies for general attitudes towards foreign policy preferences.

The second set of data consists of experimental surveys designed to ascertain how Americans think about foreign policy in the abstract. The advantage of these experiments is that they allow the researcher to vary the scenario parameters, determining how sensitive public opinion is to changes in external circumstances. The disadvantage to this survey methodology is that, because these scenarios are hypothetical in nature, there is reason to question whether the respondents have fully thought out their answers. It is possible that respondents who are willing to support a policy in the abstract could change their minds when confronted with a real-world variant of the scenario. ${ }^{46}$

One final observation: it is logical to expect that the easiest test for the anti-realist assumption should come from polling data taken during the interregnum between the end of the Cold War and the September 11 attacks. During the Cold War and the post-9/11 periods, the United States faced a clear, paramount, external threat. One would expect Americans to be more comfortable with realpolitik 
when the threat environment is high. During the nineties, American power was unrivaled and the threat environment was low. Polling data strongly suggests that Americans knew this fact. ${ }^{47}$ If individuals rank foreign policy priorities like a Maslovian "hierarchy of needs," one would expect Americans to be more enthusiastic about liberal principles during the nineties - once realist concerns were sated.

\section{American Public Opinion on Foreign Policy Worldviews and Priorities}

To determine the sources of American attitudes towards foreign policy attitudes in a post-9/11 world, Paul Brewer led a series of panel studies to determine how much Americans trusted other countries. ${ }^{48}$ What they found was that Americans were cynical about the outside world. Over 70 percent of respondents agreed that "the U.S. can't be too careful" in dealing with other countries. And 65 percent of Americans rejected the idea that other countries try to help the U.S.; instead, they said that other countries were "just looking out for themselves." Brewer et al. concluded that "most Americans see the realm of international relations as resembling the 'state of nature' described by Hobbes. Put more simply, they see it as a 'dog-eat-dog' world." 49

One could argue that such a Hobbesian outlook was simply a post-9/11 anomaly. However, survey evidence shows that American attitudes about the international system were not all that different during the nineties. The Pew Research Center conducted surveys in 1994 and 1999 that asked Americans about trusting other countries. In both surveys, more than 70 percent of respondents believed that other countries took unfair advantage of the United States. The numbers were not significantly different between the two surveys. Brewer concludes that "trust appears to be the exception, rather than the rule," during both the pre and post-9/11 worlds. ${ }^{50}$ Public Agenda's foreign policy polling — conducted in summer 2005 and winter 2006-confirms the self-interested nature of the American public. ${ }^{51}$ In both surveys, more than 60 percent of respondents agreed that the United States was "already doing more than our share to help out less fortunate countries." 52 Like realists, an overwhelming majority of Americans view the world through a Hobbesian prism.

There is also evidence that Americans do not subscribe to key components of the liberal world view. When asked whether it was right, wrong but sometimes necessary, or always wrong for the U.S. to cooperate with "harsh, undemocratic governments" in order to fight terrorism, less than 15 percent said it would always be wrong; 64 percent said it was wrong but sometimes necessary. While a slim majority agreed with the contention that more democracies reduce global conflict and violence, a slim majority disagreed with the contention that less poverty in the world does the same. ${ }^{53}$ Given bipartisan support among elites for both of these contentions in recent years, the weak level of mass public support is surprising. Contrary to an absolute gains perspective, Benjamin Page and Marshall Bouton find a majority of Americans oppose the idea of the European Union acquiring superpower status. They conclude that "just as 'realist' international relations theorists might hope (but not expect), most Americans are comfortable with the idea of the United States as the world's sole military superpower." 54

What about foreign policy priorities? In the summer of 2004, the Council on Foreign Relations and Pew Research Center released a poll on American foreign policy attitudes that appeared to confirm the anti-realist assumption. Analyzing the data, Lee Feinstein, James Lindsay, and Max Boot concluded that "Realpolitik does not play well with the American public. . . . Americans overwhelmingly believe that morality should influence foreign policy decisions." 55 Indeed, when asked what values should guide American foreign policy, 72 percent of respondents agreed that "moral principles" should be the guiding light in U.S. foreign policy.

However, when Americans were asked which issues should be thought of as "top priorities," the responses suggest a public that is much more comfortable with realism than previously thought. Table 2 reveals that policy priorities conventionally categorized in the "legal-moral" tradition-promoting democracy, advocating for human rights, and strengthening the United Nations-are considered low-priority options. The only clearly liberal issue that earned more than 70 percent support was the prevention of AIDS and other epidemics. ${ }^{56}$ In contrast, realist priorities - protecting against terrorist attacks, protecting American jobs, insuring adequate energy supplies-all scored better than 70 percent support. As table 2 shows, this preference ordering remains consistent, even when looking at polls taken prior to the September 11 terrorist attacks.

These two results hint at a pattern of American attitudes towards foreign policy priorities. Americans possess aspirations for liberal internationalism, but when asked to rank order priorities, realist principles come to the fore. Table 3 looks at the CCGA data on top foreign policy priorities over the past 30 years, and finds a similar result to the Pew/CFR surveys. Over the past few cycles, realist policy priorities, emphasizing security and autonomy, consistently earn more than 60 percent support from the mass public. Liberal policy priorities, emphasizing multilateralism, democracy and human rights, consistently earn less than 50 percent support. As figure 1 demonstrates, the top-ranking policy priorities for the past three decadesprotecting American jobs, securing energy supplies-have a realist cast to them. In contrast, Americans have consistently placed less importance on liberal internationalist policy priorities_-democracy promotion, human rights, 


\begin{tabular}{|c|c|c|c|}
\hline \multirow[b]{2}{*}{ Issue area } & \multicolumn{3}{|c|}{$\begin{array}{l}\text { Percentage of Americans } \\
\text { considering issue a } \\
\text { "top priority" }\end{array}$} \\
\hline & $\begin{array}{l}\text { Early } \\
\text { September } \\
2001\end{array}$ & $\begin{array}{l}\text { October } \\
2001\end{array}$ & $\begin{array}{l}\text { July } \\
2004\end{array}$ \\
\hline Protect against terrorist attacks & 80 & 93 & 88 \\
\hline $\begin{array}{l}\text { Protect jobs of American } \\
\text { workers }\end{array}$ & 77 & 74 & 84 \\
\hline $\begin{array}{l}\text { Reduce spread of AIDS \& } \\
\text { other diseases }\end{array}$ & 73 & 59 & 72 \\
\hline $\begin{array}{l}\text { Stop spread of weapons of } \\
\text { mass destruction }\end{array}$ & 78 & 81 & 71 \\
\hline $\begin{array}{l}\text { Insure adequate energy } \\
\text { supplies }\end{array}$ & 74 & 69 & 70 \\
\hline $\begin{array}{l}\text { Reduce dependence on } \\
\text { foreign oil }\end{array}$ & - & - & 63 \\
\hline $\begin{array}{l}\text { Combat international drug } \\
\text { trafficking }\end{array}$ & 64 & 55 & 63 \\
\hline $\begin{array}{l}\text { Distribute costs of maintaining } \\
\text { world order }\end{array}$ & 56 & 54 & 58 \\
\hline $\begin{array}{l}\text { Improve relationships with } \\
\text { allies }\end{array}$ & - & - & 54 \\
\hline $\begin{array}{l}\text { Deal with problem of world } \\
\text { hunger }\end{array}$ & 47 & 34 & 50 \\
\hline Strengthen the United Nations & 42 & 46 & 48 \\
\hline $\begin{array}{l}\text { Protect groups threatened with } \\
\text { genocide }\end{array}$ & 49 & 48 & 47 \\
\hline Deal with global warming & 44 & 31 & 36 \\
\hline $\begin{array}{l}\text { Reduce U.S. military } \\
\text { commitments }\end{array}$ & 26 & - & 35 \\
\hline $\begin{array}{l}\text { Promote U.S. business } \\
\text { interests abroad }\end{array}$ & 37 & 30 & 35 \\
\hline Promote human rights abroad & 29 & 27 & 33 \\
\hline Solve Israeli/Palestinian conflict & - & - & 28 \\
\hline Promote democracy abroad & 29 & 24 & 24 \\
\hline $\begin{array}{l}\text { Improve living standards in } \\
\text { poor nations }\end{array}$ & 25 & 20 & 23 \\
\hline
\end{tabular}

Source: Pew/CFR survey, "Foreign Policy Attitudes Now Driven by $9 / 11$ and Iraq," http://people-press.org/reports/display.php3? PagelD=865, August 2004.

and strengthening the United Nations. These results are stable across the three different time periods, despite variation in the level of international threat. ${ }^{57}$ These results are also consistent across survey instruments. ${ }^{58}$ Intriguingly, support for liberal policy priorities fell during the nineties - at exactly the point when the anti-realist assumption would have presumed the opposite to the true.

Sam McFarland and Melissa Matthews come to a similar conclusion about American attitudes towards human rights promotion. They find that Americans give strong support for abstract human rights principles - but when asked to rank order policy priorities, human rights came in 12th out of 15 possibilities. They conclude that, "although most Americans express agreement with the ideals of human rights, a willingness to commit American resources to promote and defend human rights is much

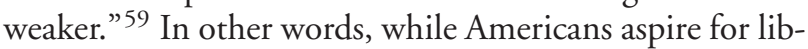
eral policy ends, realist considerations of national interest trump those aspirations.

The CCGA surveys do reveal one trend that would, at first glance, support the anti-realist assumption. Most
Americans strongly support multilateral institutions like the United Nations and NATO. More than 70 percent of Americans supported American participation in the International Criminal Court and the Kyoto Protocol to protect global warming. ${ }^{60}$ Healthy majorities of Americansincluding conservatives and Republicans-support giving up America's veto in the UN Security Council if it meant a more effective global body. Similar majorities endorse giving the UN limited powers of taxation to raise a standing multilateral force. In questions about going to war or deploying American forces as peacekeepers, public support is highly contingent on whether there is multilateral support.

A second cut at the data, however, suggests a realist motivation behind the support for multilateral institutions. The major reason Americans support international organizations is because they can facilitate burdensharing. In the 2002 CCGA survey, for example, by 71 percent to 17 percent, Americans preferred the U.S. to "do its share to solve international problems together with other countries" over "be[ing] the preeminent world leader to solve international problems." 61 That survey also showed that, in the Middle East, over 80 percent support "the European Union [to] be more involved in the negotiations while also bearing more of the political and economic costs." ${ }^{62}$ Americans view multilateralism both a means of enhancing global governance and as a means of redistributing costs from the United States to other countries. $^{63}$

A closer examination of public attitudes towards the ICC and the Kyoto Protocol also shows that support for multilateralism in principle is soft. Although a majority of Americans endorse the ICC in the abstract, for example, they also oppose allowing U.S. soldiers to be tried in The Hague. This is in sharp contrast to France, Germany, and the U.K, where majorities supported having their soldiers tried by the ICC. Similarly, on global warming, a strong majority of Americans want poorer countries to bear as much of the burden in dealing with global warming as richer nations. ${ }^{64}$ Sifting through the Pew data, Andrew Kohut and Bruce Stokes conclude that, "If asked to choose, Americans prefer proactive, assertive unilateral action to multilateral efforts beset by delay and compromise." 65

A 2006 Bertlesmann Foundation poll crystallizes how Americans think about international cooperation. ${ }^{66}$ When asked to choose between the best framework for ensuring peace and security, the populations of most major powers prefer "a system led by the United Nations" over either a balance of regional powers or a unipolar world. The United States was the only country in the survey where a majority supported the balance of regional powers over the UN. Whereas other countries value multilateralism as an intrinsic good, Americans view it instrumentally-as a means to advance American interests while reducing enforcement costs. ${ }^{67}$ 


\section{Table 3}

Foreign policy priorities, 1991-2006

\begin{tabular}{|c|c|c|c|c|c|c|}
\hline Policy Goal & 2006 & 2004 & 2002 & 1998 & 1994 & 1990 \\
\hline Protect against terrorist attacks & 72 & 71 & 91 & 79 & - & - \\
\hline Protect jobs of American workers & 76 & 78 & 85 & 80 & 83 & 65 \\
\hline Stop spread of weapons of mass destruction & 74 & 73 & 90 & 82 & 82 & 59 \\
\hline Controlling and reducing illegal immigration & 58 & 59 & 70 & 55 & 72 & - \\
\hline Insure adequate energy supplies & 72 & 69 & 75 & 64 & 62 & 61 \\
\hline Stopping the flow of illegal drugs into the U.S. & - & 63 & 81 & 81 & 85 & - \\
\hline Reducing our trade deficit with foreign countries & - & - & 51 & 50 & 59 & 56 \\
\hline Maintaining superior military power worldwide & 55 & 50 & 68 & 59 & 50 & - \\
\hline Deal with problem of world hunger & 48 & 43 & 61 & 62 & 56 & - \\
\hline Strengthen the United Nations & 40 & 38 & 57 & 45 & 51 & 44 \\
\hline Improving the global environment & 54 & 47 & 66 & 53 & 58 & 58 \\
\hline Promote U.S. business interests abroad & - & 32 & 49 & - & - & 63 \\
\hline Promote human rights abroad & 28 & - & 47 & 39 & 34 & 58 \\
\hline Promote democracy abroad & 17 & 14 & 34 & 29 & 25 & 28 \\
\hline Improve living standards in poor nations & 22 & 18 & 30 & 29 & 22 & 41 \\
\hline
\end{tabular}

\section{American Public Opinion on the Use of Force}

The debate about mass public attitudes towards the use of force revolves around two kinds of survey questions. The first set asks Americans whether they would support a future use of force. These questions vary with the proscribed mission and the anticipated adversary. The second set of questions polls Americans on their support of imminent or ongoing military interventions - either wars or other kinds of troop deployments, such as peacekeeping missions. If the anti-realist assumption holds, we should expect to see public enthusiasm for military interventions into genocides, civil wars, and humanitarian relief operations. Support for these activities is expected to decline, however, as casualties begin to mount.

The responses to hypothetical scenarios strongly refute the anti-realist assumption. Richard Herrmann, Philip Tetlock, and Penny Visser found in their surveys a strong predisposition towards balancing behavior among the mass public:

Rather than be deterred by the potential costs of confronting a strong opponent, participants were more willing to intervene against a powerful aggressor than a weak aggressor. . . despite the reminder that such an endeavor would require a major military effort. Evidently, they paid more attention to the long-range threat posed by a powerful enemy if not checked than to the immediate costs of fighting. ${ }^{68}$

Herrmann et al. achieved similar results when questions regarding nuclear proliferation and the prior behavior of possible adversaries were posed. Americans were more likely to prefer tougher responses to states that had acquired nuclear weapons and states with "revisionist motives" in the international system. ${ }^{69}$ These responses are fully consistent with the balance-of-power logic stressed by realists.

Other experiments have yielded similar results. Peter Feaver and Christopher Gelpi asked military elites, civilian elites, and mass publics about their attitudes towards the use of force. They found that across the board, respondents ranked the realist goals as more important than the interventionist or humanitarian goals. ${ }^{70}$ The mass public was also just as supportive of realpolitik missions - and just as tolerant of civilian casualties - as civilian elites. ${ }^{71}$ The CCGA surveys found Americans thinking about the use of force in the same way as offshore balancers. The mass public's strongest support for the use of force came in missions close to home-interdicting illicit drugs, combating terrorism, and armed interventions in Latin America. ${ }^{72}$

Analyses of polling during real world applications of force also contradict the anti-realist assumption. The first, overriding metric that Americans use to gauge their support for war is whether the operation appears to be successful. Most scholars have found a "halo effect" that comes from successful uses of force. ${ }^{73}$ As Richard Eichenberg summarizes this work, "quite simply, successful military operations enjoy high support, even when the objective is unpopular and casualties are suffered." 74 This rationalist result is consistent with several foreign policy paradigms, including realism. The finding does undercut the Almond-Lippmann consensus, however-and the antirealist assumption rests partly on that consensus.

Beyond the importance of perceived success, Americans appear to have realist instincts in placing a value of the uses of force. Table 4 demonstrates the mean level of support for American uses of force between 1981 and 


\section{Figure 1}

Foreign policy priorities, 1974-2004

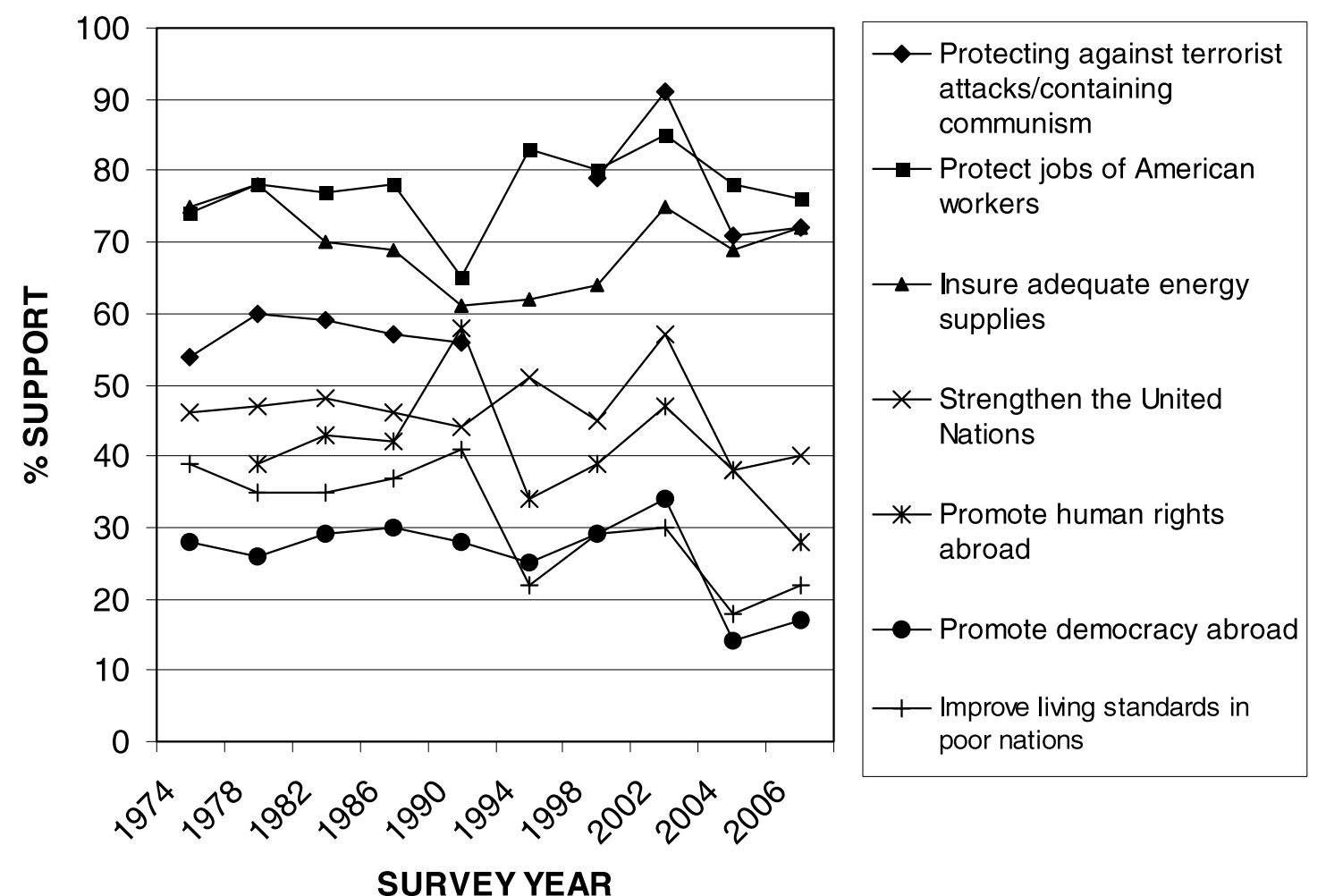

Source: Chicago Council on Global Affairs, "Public Opinion \& Foreign Policy," available at http://www.thechicagocouncil.org/ past_pos.php

1995, as collected by Richard Eichenberg. ${ }^{75}$ Two facts stand out immediately. First, the only examples of military statecraft that garnered more than 60 percent support from the American people were realpolitik missions: retaliating against al Qaeda attacks, compelling Saddam Hussein to withdraw from Kuwait, and preventing Hussein from acquiring weapons of mass destruction (further discussion of the second Gulf War follows). Second, the only missions that garnered less than 50 percent support can be categorized as humanitarian or peacekeeping interventions: the uses of force in Liberia, Kosovo, Bosnia, Lebanon, and Haiti. This is fully consistent with David Burbach's conclusion that "the public is quite negative towards restoring order in countries where American lives are not at stake. ${ }^{76}$

The empirical literature on public responses to war and other uses of force also undercut the anti-realist assumption. Testing public reaction to thirty-eight uses of force during the Cold War era, John Oneal, Brad Lian, and James Joyner found that Americans were more likely to support the use of force to repel armed aggression than to intervene in civil conflicts. They concluded that "the public evaluates the use of force pragmatically and in a way consistent with fundamental international principles regarding sovereignty and self-determination." ${ }^{77}$ Eichenberg found similar results: Americans provided significantly more support for uses of force that involved restraining foreign aggressors than other kinds of military intervention. $^{78}$

One possible counterexample to these findings is the apparent contrast between public and realist attitudes about the invasion of Iraq in 2003. Most realists opposed the invasion of Iraq, while by March 2003 the American public largely supported the invasion-ostensibly in reaction to the Bush administration's public relations campaign. ${ }^{79}$ This could be viewed as support for the anti-realist assumption. However, this case is at best ambiguous. First, public support for the war was highly contingent on the survey question. Philip Everts and Pierangelo Isernia point out that "when different alternatives to deal with Saddam's regime were offered, a plurality if not a majority of the American public would opt for the softer ones." ${ }^{80} \mathrm{Sec}-$ ond, the Bush administration used realist rhetoric to make the case for invading Iraq. Mearsheimer characterized the Bush administration's case for eliminating Saddam Hussein's weapons of mass destruction program as a "hardnosed realist argument." Other security scholars concur, labeling the official rhetoric as, "a Realist logic focused on 


\begin{tabular}{|c|c|c|c|}
\hline Mission & Year(s) & $\%$ in favor & $\begin{array}{l}\text { Number } \\
\text { of polls }\end{array}$ \\
\hline War against terror & $2001-2003$ & 79 & 75 \\
\hline $\begin{array}{l}\text { Sudan/Afghanistan missile } \\
\text { strikes }\end{array}$ & 1998 & 73 & 5 \\
\hline $\begin{array}{l}\text { Second Gulf War, major } \\
\text { combat phase }\end{array}$ & 2003 & 72 & 38 \\
\hline First Gulf War & 1990-1991 & 64 & 63 \\
\hline Conflicts with Iraq & 1992-2003 & 62 & 244 \\
\hline Grenada & 1983 & 59 & 8 \\
\hline Libyan air strikes & $1981-1988$ & 59 & 10 \\
\hline Kuaiti tanker re-flagging & $1987-1988$ & 58 & 18 \\
\hline Somalia & $1992-1993$ & 56 & 41 \\
\hline Panama & 1988-1989 & 52 & 18 \\
\hline $\begin{array}{l}\text { Second Gulf War, } \\
\text { occupation phase }\end{array}$ & $2003-2005$ & 50 & 84 \\
\hline Liberia & 2003 & 50 & 7 \\
\hline Kosovo & $1998-2001$ & 49 & 99 \\
\hline Bosnia & 1992-2002 & 46 & 141 \\
\hline Lebanon & $1982-1984$ & 40 & 26 \\
\hline Haiti & 1992-1995 & 37 & 50 \\
\hline
\end{tabular}

Source: Eichenberg 2005, Table 2.

response to threat." ${ }^{81}$ High-ranking officials might have had non-realist motivations for going to war, but they were also conscious that these motivations did not resonate with the mass public. ${ }^{82}$ If the administration used realist rhetoric and shied away from non-realist rhetoric to make its case for war, then Operation Iraqi Freedom provides no support for the anti-realist assumption.

Another prediction that flows from the anti-realist assumption is that Americans should not be able to stomach casualties during combat. However, multiple reviews of casualty data with public support for military deployments contradict this expectation. Eric Larson concludes that the public's aversion to losses of U.S. life in military interventions has less to do with intolerance for casualties than with the debatable merits of the operations themselves. Multivariate analyses shows that casualties in and of themselves do not cause an erosion of public support; Americans compare these costs to the possible benefits from victory. ${ }^{83}$ Furthermore, process tracing of highprofile military reversals suggest that such events trigger rally-round-the-flag effects. For example, after the October 1993 "Black Hawk down" incident in Mogadishu, public support for the Somalia mission to temporarily increased. ${ }^{84}$ Nevertheless, the sensitivity of democratic publics to casualties remains an open debate. ${ }^{85}$

With regard to public opinion polling on different types of armed interventions, the results again support a realpolitik mass public. McFarland and Matthews found consistent results when polling Americans about the use of force to prevent genocide or ethnic cleansing. Seven years after the Rwandan genocide, they found only 26 percent of respondents supporting the use of U.S. troops to halt the genocide, while 41 percent preferred to "not become involved." When asked whether the U.S. military should be used more or less often to stop either mass killings or ethnic cleansing, there was plurality support (38 percent to 15 percent) for curtailing activity. In June 1999, support for sending U.S. ground troops into Kosovo as part of a NATO operation to serve in a combat situation registered only 40 percent support. ${ }^{86} \mathrm{McF}$ arland and Matthews conclude, "Although most Americans applaud human rights principles, the American public en masse does not appear to care enough about human rights to invest significant American resources and troops to defending them, even in grave situations of genocide and ethnic cleansing." ${ }^{87}$

Turning back to the question of multilateralism, surveys conducted by the German Marshall Fund of the United States, the Program on International Policy Attitudes (PIPA), and CCGA show that multilateral backing also has a dramatic effect on American support for activities like armed interventions. ${ }^{88}$ For example, the 2002 CCGA survey shows that American support for defending South Korea against an invasion from North Korea increases from 36 percent to 57 percent if the effort is UN sponsored. This would seem to be consistent with a liberal worldview.

Further examination, however, suggests a realist logic is at work. The increases in public support for defending vital allies came when the question specifically said that the United States would be "contributing forces together with other countries." ${ }^{89}$ Ceteris paribus, even academic realists evinced strong support for the use of force when such action receives multilateral backing. ${ }^{90}$

The question is whether the mass public desires multilateral outcomes if all else is not equal. Compared to other countries, Americans still favor reserving the right to use preemptive military force to a much greater extent than Europeans. Kohut and Stokes conclude that "the American public looks primarily to its own military for its self-defense." 91 Bruce Jentleson and Rebecca Britton found that between 1992 and 1998, Americans preferred unilateral over multilateral operations when the mission was one of foreign policy restraint. At the same time, when the mission was perceived to be humanitarian in nature, there was a strong preference for multilateral participation. ${ }^{92}$ This result suggests that collectively, Americans have an intuition about applying realist principles to realist situations and liberal principles to liberal situations. When large-scale war is expected, Americans believe in self-help; when the mission is more consistent with liberal internationalism, however, Americans prefer using multilateralism as a way to redistribute costs. ${ }^{93}$

\section{American Public Opinion on Foreign Economic Policy}

Since the beginning of modern polling, there has been public suspicion about the merits of free trade. This suspicion 
remains even during boom times. In 1953 - a time when the U.S. was running a massive trade surplus — a plurality of Americans supported greater import restrictions over greater import expansion. ${ }^{94}$ During the sixties, mass survey research revealed a strong protectionist bent among Americans. ${ }^{95}$ In 1998 - when the late-nineties boom was well under way - a majority of respondents agreed that, "foreign trade has been bad for the U.S. economy." 96 Kenneth Scheve and Matthew Slaughter have catalogued a persistent fact throughout the late nineties; majorities of Americans repeatedly affirmed that a) the costs from more imports always outweighed the benefits of more imports; and b) the costs from more imports exceeded the benefits from more exports. ${ }^{97}$ Polls conducted by the Chicago Council on Foreign Relations, the German Marshall Fund, and the Foreign Policy Association in the past decade all confirm that a strong majority of the American public is suspicious about trade liberalization. ${ }^{98}$ One PIPA assessment observes that "questions that do not emphasize trade in principle, but rather how it has been practiced, find quite modest levels of [public] support." 99

The debates over offshore outsourcing offer an even more pungent example of a mercantilist public at work. ${ }^{100}$ Beginning in 2004, there was a marked increase in media coverage about this newer form of economic interdependence. Consistent with overall views about the costs and benefits of international trade, a majority of Americans stated that offshoring is a serious economic problem. An Associated Press poll in May 2004 found that 69 percent of Americans believe outsourcing hurts the U.S. economy. A Marlin Company poll found that 53 percent of Americans believed that it was unpatriotic for American firms to send jobs overseas. ${ }^{101}$ An Employment Law Alliance poll taken the same month found that 58 percent of American workers believed the federal government should penalize companies that send work offshore. A Watson Wyatt survey a few months later found 85 percent of American workers believing that the practice has a negative effect on the U.S. economy. ${ }^{102}$ These attitudes have persisted. A March 2006 Pew Research poll found 71 percent of Americans believed that outsourcing was bad for the U.S. economy. ${ }^{103}$ In the wake of the 2006 midterms, pollsters argued that voters specifically rewarded politicians who espoused mercantilist themes. ${ }^{104}$

What is the source of the mass hostility to trade expansion? A non-realist explanation is that people are responding out of self-interest rather than the national interest. Scheve and Slaughter argue that respondents with lower education and income status are more likely to project mercantilist opinions about trade. ${ }^{105}$ However, this is only a partial explanation. For example, neither class nor educational status can explain why, between 1999 and 2004, public support for free trade declined across the board. ${ }^{106}$ Similarly, this does not explain the intense opposition to offshore outsourcing. The Watson Wyatt survey, for exam- ple, found that while American workers were very concerned about its impact on the economy as a whole, they evinced little concern about how it affects their personal situation. ${ }^{107}$

While individual economic factors undoubtedly play a role in determining opinions about trade, there is strong evidence that realpolitik considerations of national interest also play an important role. Ronald Inglehart, Neil Nevitte, and Miguel Basanez conclude that "free trade galvanizes concern for a much wider set of issues, such as cultural integrity and national identity." 108 Other scholarly studies have found a similar correlation between support for mercantilism and national pride or concerns about American sovereignty. ${ }^{109}$ As previously noted, the protection of American jobs has consistently ranked among the most important of foreign policy priorities.

A recent example of realism driving American policy attitudes towards foreign economic policy comes in the wake of the March 2006 Dubai Ports World controversy. A Pew survey found that 58 percent of Americans supported Congress acting to block Dubai Ports World from operating port terminals in six American cities. The framing of questions surrounding foreign direct investment revealed a key driver of mass public opposition on this issue is a loss of economic autonomy. On the one hand Americans approved of "companies in other countries investing in the U.S." by 53 percent to 36 percent. On the other hand, Americans disapproved of "investors from other countries owning companies in the U.S." by 53 percetn to 33 percent. ${ }^{110}$ The difference between investment and control relates to questions about national sovereignty-a realist theme.

Experimental survey results confirm the strong bias in favor of relative gains concern among the mass public of Americans. Informal surveys by Robert Reich found a high degree of relative gains concern vis-à-vis Japan in 1990the peak of Japan's perceived threat to U.S. economic hegemony. ${ }^{111}$ Richard Herrmann, Philip Tetlock, and Matthew Diascro asked whether respondents would support a foreign economic policy that benefited the United States more than its trading partner, benefited both countries equally, or benefited the trading partner more (in all cases, both countries received positive benefits). Among the mass sample, the distribution of gains significantly affected responses-64 percent of Americans supported a policy that benefited the United States more; when the partner benefited more, support fell to 38 percent. ${ }^{112}$ Mass responses were also more protectionist when the trading partner was described as either wealthy or strong. Using real world countries, respondents were more likely to favor restricting trade against Japan than either England or India. Herrmann, Tetlock, and Diascro conclude that "a larger percentage of the general public than of the elite think about trade as if they were intuitive neorealists. ... And more of them are sensitive to the factors neorealists 
say should affect policy calculations." ${ }^{113}$ David Rousseau conducted a similar survey, and found majorities opposing trade agreements that resulted in small economic gains for the United States but significant economic gains by other major powers. Consistent with realism, opposition increased when the proposed trade partner was a country viewed as an economic challenger, such as China or Japan. ${ }^{114}$

\section{How Robust Are These Results?}

The experimental and survey data suggests that Americans do not reject realist principles in their thinking about foreign policy. Indeed, Americans share a lot of intuitions with realists. That said, there may still be methodological reasons to argue that the anti-realist assumption should still be privileged. Different components of the mass public can hold different images of foreign affairs. This paper has treated the mass public as an undifferentiated whole, but most public opinion research finds that factors such as education, income status, political ideology, party affiliation, and prior military service affect individual attitudes towards foreign policy. ${ }^{15}$ There is likely to be a slice of the American public that is hostile to realpolitik, just as there is a slice that is hostile to liberal internationalism. Feaver and Gelpi, for example, find that 20 percent of Americans are casualty-phobic-but there exist an equal or greater number of defeat-phobic Americans. ${ }^{116}$ If these different components of the mass American public hold transitive preferences over foreign affairs, it could lead to the type of cycling and instability consistent with the Almond-Lippmann hypothesis.

Another issue is the sensitivity of survey responses to framing effects. ${ }^{117}$ For example, questions about trade liberalization register majority support if costs are not mentioned. Michael Hiscox argues that the framing effects of trade questions are particularly powerful: respondent support for trade dropped 19 percent on average when cost factors were included in the question. Hiscox concludes that research relying upon existing surveys to gauge attitudes towards trade and globalization rest on an "unstable foundation." "118 A related problem is that the mass public is so uninformed about foreign affairs that just a small dollop of information has the potential to change preference orderings. Steven Kull and I.M. Destler found that public hostility to foreign aid flows was based in part on a lack of information about the actual size of U.S. development assistance. Once informed of the true facts, public support for boosting foreign aid shoots up dramatically. ${ }^{119}$

While these methodological problems should be kept in mind, none of them pose serious challenges to the arguments presented here. The existence of different components of the American public fails to undercut the evidence presented here. What is striking about the aggregate data is that American foreign policy attitudes have been con- sistent over a long period of time, despite the end of the Cold War and the September 11 terrorist attacks. This is consistent with arguments made within the literature that mass public opinion is more structured and stable than Almond or Lippmann posited a half-century ago. ${ }^{120}$ The stability of opinion polling on the salient foreign policy questions over the past decades suggests that preference transitivity is not a problem. Furthermore, the swing in support for certain policy questions suggests that realists occupy the middle ground in the public spectrum between isolationists and liberal internationalists. Median voter arguments suggest that this makes the opinions of realistminded Americans more salient, not less. ${ }^{121}$

As for framing effects, it is undeniable that public opinion responses vary considerably in response to how questions are framed. Recall, however, that the anti-realist assumption implies that realists cannot hawk their policy wares to American because they are ideationally hardwired to dislike realpolitik. The fact that questions can be framed in a way that elicits a realist response directly refutes this claim. It is perfectly possible to articulate a set of foreign policy principles in a realist frame and have them accepted by the American people. ${ }^{122}$ Indeed, when balanced against the bulk of the survey evidence, the worst conclusion one could draw from these caveats is that Americans are just as comfortable with realism as they are with any other paradigm of international relations. In the court of American public opinion, realists are not handicapped in any way whatsoever.

One possible explanation for the mass public's receptivity to realism is that their rational ignorance of world politics engenders a kind of "folk realism." 123 A persistent finding in survey research is that the American public is largely uninformed and uninterested in world politics. This lack of information - and the uncertainty created by it - can impose a structure on attitudes towards the rest of the world that is sympathetic to realism. Realists assert that uncertainty about other countries' intentions forces states to act in ways that bolster their security. Perhaps Americans, when asked about foreign affairs, react in a similar manner-focusing on prudence and self-defense as risk-averse responses to an environment that they find complex and opaque.

The one criticism that is difficult to contest is the dearth of survey questions and results that directly address whether Americans think like realists or liberal internationalists. Most of the longstanding questions in the CCGA, Pew, and other surveys are designed to examine whether Americans are isolationists or internationalists. Herrmann and Tetlock's experimental surveys are more explicitly designed to test the anti-realist assumption - but it is not the primary focus of their research. Clearly, further survey and experimental work is needed to conclusively determine whether the mass American public holds intuitions that resonate strongly with a particular international relations paradigm. 


\section{Why Does the Anti-Realist Assumption Persist?}

This paper concludes that the anti-realist assumption is not empirically valid. Americans do hold some liberal aspirations for their conduct across the globe, and believe that morality should play a role in foreign affairs - in the abstract. However, surveys about foreign policy world views and priorities, the use of force, and foreign economic policies all reveal a strong realist bent among the mass American public. The overwhelming majority of Americans possess a Hobbesian world view of international relations. Americans consistently place realist foreign policy objectivesthe securing of energy supplies, homeland security - as top foreign policy priorities. Objectives associated with liberal internationalism — strengthening the United Nations, promoting democracy and human rights-rank near the bottom of the list. On the uses of force, experimental surveys reveal that Americans think like intuitive neorealists; they prefer balancing against aggressive and rising powers while remaining leery about liberal-style interventions. On foreign economic policy, Americans think of trade through a relative gains prism, particularly if the trading partner is viewed as a rising economic power. Surveys and polling do suggest that Americans like multilateral institutions, but they appear to like them for realist reasons - they are viewed as mechanisms for burden-sharing. Liberal internationalist attitudes did not resonate more during the nineties, the period when the anti-realist assumption should have had the greatest support. If anything, during that decade Americans appeared to adopt attitudes consistent with offshore balancing.

The implications of these results for the analysis of American foreign policy are significant. Realists have repeatedly asserted that U.S. foreign policy leaders act in a realist manner but disguise these actions through liberal rhetoric. The anti-realist assumption allows these scholars to assert that the only source of realpolitik behavior comes from the systemic level. If the American public holds realist views on certain foreign policy dimensions, then a unitlevel causal mechanism exists that would also explain these policy outcomes.

These findings also lead to an important question. If American attitudes towards foreign policy have been consistent for decades, and those attitudes are receptive to a realist world view, then why does the anti-realist assumption persist within the academy and the policymaking worlds? One possible explanation is that, even at the elite level, misperceptions about public opinion are remarkably difficult to change. Public opinion scholars refer to this phenomenon as "pluralistic ignorance" - shared but incorrect beliefs about what other people think. Americans believe that a majority hold views similar to the actual outputs of U.S. foreign policy. ${ }^{124}$ It is possible, then, that realists commit a double error in their analysis of American foreign policy. They assert that Americans take realist actions against the desires of a liberal public. The reverse might be true- because the United States pursues a liberal foreign policy, Americans assume that the majority supports these policies even if that is not actually the case.

Another possible explanation is that realist scholars believe the anti-realist assumption because they encounter hostility to realism on a daily basis. Hostility to realism resides in the elite public more than the mass public. Most survey research in foreign policy-including the Foreign Policy Leadership Project-separate out elite opinions from the mass public. The elite public is usually defined as people who are both knowledgeable about foreign affairs and have some access to foreign policy decision-makers. This includes high-ranking members of the executive branch, members of Congress and their staffs, lobbyists and interest group representatives, journalists, academics, and leaders of labor, business, and religion. ${ }^{125}$ Researchers have identified persistent gaps in attitudes between the mass public than the elite public on a series of foreign policy issues. ${ }^{126}$ Realists would predict this gap to exist; they assume that the mass public is hostile to hard-headed calculations, requiring the elite public to think in a realpolitik fashion behind closed doors. ${ }^{127}$

However, many of the studies cited here also find that across a broad array of questions, the elite public is more liberal internationalist than the mass public. ${ }^{128}$ During the mid-nineties, the mass public was significantly more pessimistic about world affairs than policymakers. ${ }^{129}$ Elites adopted more positive attitudes towards multilateralism. ${ }^{130}$ Elites prefer spending larger amounts of foreign aid than the mass public. Military elites are more casualtyphobic than the civilian mass public. ${ }^{131}$ After the end of the Cold War, the elite public was far more concerned about Russia's transition to democracy than the American public; the mass public was more concerned about Japan's economic ascent and the threat of international terrorism. On the use of force, the mass public was more willing to use military statecraft to intervene in the Western hemisphere, combat illegal drugs, and prevent terrorism than the elite public. In the months after the September 11 terrorist attacks, the elite public evinced a more cosmopolitan policy response than the mass public. ${ }^{132}$

Foreign economic policy is where the most prominent gap between elite and mass public opinion exists. In their experimental surveys, Herrmann, Tetlock, and Diascro found that elite participants were far less sensitive to relative gains than most Americans: "even in the condition of a ten-to-one relative loss, more than two-thirds of elite Americans still pursue absolute gains and choose free trade." ${ }^{133}$ The CCGA surveys reveal a similar gap between the elite and mass publics on questions of trade, investment and immigration. Over the course of the eight surveys, the elite public has consistently favored freer trade, been less exercised about the trade deficit, and preferred 
higher levels of legal immigration. Other public opinion researchers have detected similar gaps between the elite and mass publics. ${ }^{134}$

The gap between elites and the rest of America on trade policies have ramifications beyond foreign economic policy. Some commentators have hypothesized that in the current era of economic globalization, elite members of the American public would adopt a more cosmopolitan view of world politics, consistent with liberal internationalism. ${ }^{135}$ Samuel Huntington derisively dubbed this the "Davos culture" hypothesis, but the notion has attracted serious scholarly interest. ${ }^{136}$ Certainly a cosmopolitan elite would be less likely to embrace a "folk realism" borne out of inattention to world politics. Richard Herrmann and Jonathan Keller have found that among the American policy elite, a free trade orientation was strongly and positively correlated with supporting policies of engagement and a reluctance to use force. Not surprisingly, Herrmann and Keller found more than 60 percent support among policy elites for engaging both China and Iran. They further found that policy elites embraced the democratic peace hypothesis. ${ }^{137}$

The relatively liberal attitude of American elites comes into particular focus when one considers precisely which elites strongly influence American foreign policy. Lawrence Jacobs and Benjamin Page conclude that the preferences of four elite groups had the strongest effect on the attitudes of policymakers: media, business, think tanks and other foreign policy organizations, and educators. ${ }^{138}$ With the partial exception of think tanks, surveys of all of these different subgroups indicate a strong predilection towards cosmopolitanism or liberal internationalism. ${ }^{139}$ The correlation of preferences between these groups is so strong that Jacobs and Page conclude that a "foreign policy establishment" still exists in the United States. ${ }^{140}$

The existence of a liberal internationalist foreign policy establishment would help to explain an enduring puzzle in this area of research - why elites continually believe that the public is more isolationist than it actually is. ${ }^{141} \mathrm{It}$ is entirely possible that either the elites or the polling questions are confusing wariness about American isolationism with liberal concerns about a realist mass public. Ironically, the fear that gripped Kennan and Morgenthau in the early fifties may be completely at odds with presentday reality: America now has a realist mass public governed by a liberal internationalist elite.

This leads to a final speculative hypothesis. The liberal internationalist trend is strong among the elites that realist scholars interact with the most-other international relations professors. ${ }^{142}$ Survey research and analyses of journal articles reveal that most IR scholars believe realism to be on the wane as a tool for explaining international relations in terms of scholarship, teaching, and real-world relevance. ${ }^{143}$ It is possible that realists believe that most Americans do not like realism because the Americans they interact with the most-their professional colleaguesare hostile to the paradigm.

\section{Notes}

1 Mearsheimer 2001, 402; see also Gilpin 1996.

2 Ibid. See also Morgenthau and Thompson 1985.

3 For recent examples, see Ikenberry and Slaughter 2006 and Daalder and Lindsey 2007.

4 Hartz 1955; Krasner 1978, 335-339.

5 Liberal internationalists, on the other hand, promote the anti-realist assumption to argue that their foreign policy preferences are more in tune with the American populace. See, for example, Kull and Destler 1999.

6 For classical realism, see Morgenthau and Thompson 1985. For neoclassical realism, see Rose 1998 and Zakaria 1998. On post-classical realism, see Brooks 1997. Mearsheimer 2001 provides the exemplar of offensive realism. For a good example of defensive realism, see Snyder 1991. For a critique, see Legro and Moravcsik 1999.

7 See, specifically, Kennan 1984; Bailey 1948; Kissinger 1960, 67-77.

8 Lippmann 1955, 20; quoted in Waltz 1967, 267.

9 Lippmann 1955; Almond 1950, 1956; Key 1961; Rosenau 1961; Converse 1964.

10 Robinson 1999; Gilboa 2005. For a critique, see Strobel 1997.

11 Quoted in Mermin 1997, 385.

12 Huntington 1957, ch. 6.

13 Morgenthau and Thompson 1985, 165.

14 Kennan 1984, 93-95; see also Carr 1964, 51.

15 Kissinger 1994, 30 and 50.

16 An important exception is Waltz 1967, ch. 4 and 10 . He argued that democratic publics were perfectly capable of accepting realist principles.

17 Another, lesser strand of realist criticism-which will not be discussed here-argues that the power of particularistic interest groups distorts how the pubic thinks about foreign policy. For a recent example, see Mearsheimer and Walt 2006, 2007.

18 Krasner 1978, 335; see also Friedberg 2000.

19 Mearsheimer 2001, 23.

20 Mearsheimer 2001.

21 Hartz 1955; Kagan 2006.

22 On national identity, see Huntington 1957, 150; Monten 2005; Kagan 2006. The first sentence of the March 2006 National Security Strategy reads: "It is the policy of the United States to seek and support democratic movements and institutions in every nation and culture, with the ultimate goal of ending tyranny in our world." Accessed at http:// www.whitehouse.gov/nsc/nss/2006/sectionI.html, July 2, 2007. 
23 George W. Bush, second inaugural address, January 20, 2005, emphasis added. Accessed at http:// www.whitehouse.gov/news/releases/2005/01/ 20050120-1.html, March 2006.

24 Lind 2006. See also Lind, "Immigrant Intellectuals and American Grand Strategy," The Globalist, April 4, 2003, 1.

25 Mead 2002, 35-55.

26 Nau 2002; Ruggie 1997; Nincic 1994.

27 Doyle 1983, 343.

28 Kagan and Kristol 2000, 22; see also Fukuyama 2006, 101.

29 Reiter and Stam 2002, 21-22; Feaver and Gelpi 2004, 4-5; Woods, Lacey, and Murray 2006.

30 McDougall 1997; Nau 2002; Mead 2002.

31 On the post-2003 renaissance of realists in the American foreign policy establishment, see Lawrence Kaplan, "Springtime for Realism," The New Republic, June 21, 2004.

32 Quote from Harry Kreisler, "Conversations with John Mearsheimer," 8 April 2002. Accessed at http:// globetrotter.berkeley.edu/people2/Mearsheimer/ mearsheimer-con4.html, March 2006.

33 Schweller 2004, 162.

34 On balancing behavior, see Waltz 1979, ch. 6, Christensen and Snyder 1990, and Schweller 2004. On power vs. security maximization, compare Waltz 1979 with Mearsheimer 2001. On grand strategy, compare Gholz, Press, and Sapolsky 1997, Layne 1997, and Layne 2006 with Art 1998/ 99, 2003.

35 Waltz 1979, 105.

36 For our purposes, the distribution of power during the period under study renders the buck-passing/ balancing debate moot. Proponents of buck-passing would agree that as a great power in a unipolar or bipolar world, the United States cannot pass the buck to any other country.

37 Walt 2005.

38 Some realists would fall under the "exemplarist" approach of promoting liberal ideas abroad by perfecting them at home. For more on exemplarism, see Monten 2005, Lieven and Hulsman 2006.

39 Mandelbaum 1996; Bacevich 2005.

40 Huntington 1957, ch. 6; Mueller 1973, 2005; Lepgold and McKeown 1995, 369-373.

41 Feaver and Gelpi 2004, 104.

42 Waltz 1979, ch. 7; Buzan 1984; Grieco 1990; Krasner 1991.

43 Gowa 1986.

44 Hirschman 1977.

45 All of the reports can be accessed online at http:// www.thechicagocouncil.org/past_pos.php. Until 2006 the CCGA was known as the Chicago Council on Foreign Relations.
46 Klarevas 2002, 424. For example, a majority of Americans claim in surveys that they would be willing to pay more for goods made according to strict labor and environmental standards. Both purchasing patterns and experimental evidence contradict this finding. See Elliott and Freeman 2003.

47 In 1986, 26 percent of Americans cited international issues as a problem for the United States; by 1998, only 7 percent made the same assertion. Rielly 1999, 8.

48 Brewer et al. 2004; Brewer 2004; Brewer, Aday, and Gross 2005.

49 Brewer et al. 2004, 105.

50 Brewer 2004, 327.

51 Ana Maria Arumi and Scott Brittle, "Public Agenda Confidence in U.S. Foreign Policy Index," Volume 2, Winter 2006. Downloaded from http://www. publicagenda.org, 15 April 2006.

52 Ibid., 20.

53 Ibid.

54 Page and Bouton 2006, 100.

55 Lee Feinstein, James M. Lindsay, and Max Boot, "On Foreign Policy, Red and Blue Voters Are Worlds Apart," Council on Foreign Relations, August 2004, 39. The Pew survey ("Foreign Policy Attitudes Now Driven by $9 / 11$ and Iraq") is available at http://people-press.org/reports/pdf/222.pdf (accessed May 1, 2006)

56 Even this response does not necessarily reflect a liberal worldview. Given American hostility to inward flows of drugs and migration, and given the 2001 anthrax scare, the concern about epidemics could be related to concerns about personal security rather than altruism. On this point, see Drezner 2007a, 184-190.

57 Page and Bouton 2006, 38-43.

58 Holsti 2004, 95.

59 McFarland and Matthews 2005a, 2005b; Holsti 1996.

60 Kull and Destler 1999, ch. 3 and 4; Page and Bouton 2006, ch. 5 .

61 Bouton 2002, 26, emphasis added. The other nine percent of respondents preferred the isolationist policy option.

62 Page and Bouton 2006, 150-1.

63 Krasner 1991.

64 Kohut and Stokes 2006, 179-180.

65 Ibid., 79.

66 "Poll of 9 Major Nations Finds All, including U.S., Reject World System Dominated by Single Power in Favor of Multipolarity," accessed at http://www. worldpublicopinion.org/pipa/articles/views_on_ countriesregions_bt/208.php?nid $=\& \mathrm{xid}=\& \mathrm{pnt}=$ $208 \& \mathrm{lb}=$ btvoc (November 2006). 
67 For more on this, see Drezner 2007b.

68 Herrmann, Tetlock, and Visser 1999, 558.

69 Ibid., 558-561.

70 Feaver and Gelpi 2004, 62. It should be noted that consistent with the liberal internationalist argument, Feaver and Gelpi also found that both mass and elite civilians were more supportive of humanitarian interventions than their military counterparts.

71 Ibid., ch. 4.

72 Page and Barabas 2000, 355-356; Page and Bouton 2006, ch. 4; Holsti 2004, 118-19.

73 Jentleson 1992; Brody 1994; Larson 1996; Jentleson and Britton 1998; Feaver and Gelpi 2005/06.

74 Eichenberg 2005, 147.

75 Eichenberg 2005.

76 Burbach 1994, 44.

77 Oneal, Lian, and Joyner 1996. See also Jentleson 1992.

78 Eichenberg 2005.

79 On realist opposition, see Mearsheimer and Walt 2003; on the malleability of the public, see Kaufmann 2004 and Western 2005.

80 Everts and Isernia 2005, 274-5.

81 For Mearsheimer's quote, see "America Amnesia interview with John Mearsheimer," http://int. usamnesia.com/Mearsheimer-2.htm. Jackson and Kaufman 2007, 98.

82 See the transcript of Sam Tannenhaus's May 2003 interview with then Deputy Secretary of Defense Paul Wolfowitz. Accessed at http://www.defenselink. mil/transcripts/transcript.aspx?transcriptid $=2594$, July 2, 2007.

83 Larson 1996; Eichenberg 2005; Feaver and Gelpi 2004, 2005/06.

84 Kull and Destler 1999, 106-108.

85 For a counterargument, see Reiter and Stam 2002, ch. 7 .

86 McFarland and Matthews 2005b, 308.

87 Ibid., 310.

88 Bouton 2002, 28; German Marshall Fund of the United States, Transatlantic Trend series, 2003-2004; Kull and Destler 1999.

89 Bouton 2002, 28; see also Kull and Destler 1999, 55 and 111.

90 Maliniak et al. 2005.

91 Kohut and Stokes 2006, 201.

92 Jentleson and Britton 1998.

93 Eichenberg 2005.

94 The precise figure was 37 percent to 24 percent. Cited in Destler 1986, 5.

95 Bauer, Pool, and Dexter 1963.

96 Scheve and Slaughter 2001, 21.

97 Ibid., ch. 2.

98 Audley and Anker 2004, 2005; Bouton 2002; Pew/ CFR, "Foreign Policy Attitudes Now Driven by
9/11 and Iraq,"; Foreign Policy Association, "Americas and the World Around Them: A Nationwide Poll," September 2004.

99 "On Balance, Feelings about Trade Lukewarm," accessed at http://americans-world.org/digest/ global_issues/intertrade/onbalance.cfm, May 2006.

100 Drezner 2005.

101 http://www.themarlincompany.com/poll/ outsourcing.htm, accessed August 10, 2004.

102 Employment Law Alliance, "Offshoring: Made in the U.S.A.," June 7, 2004. Accessed at http:// www.employmentlawalliance.com/pdf/ELA_ Offshore_Outsource_Poll_D1_5_25_04.pdf, August 6, 2004; the Associated Press poll can be accessed at http://www.ipsos-na.com/news/pdf/ media/mr040607-1tbzzz.pdf. Watson Wyatt, "Offshoring Labor," August 5, 2004. Accessed at http:// biz.yahoo.com/prnews/040805/phth035_1.html, August 10, 2004.

103 Pew Research Center, "Bush Approval Falls to 33\%, Congress Earns Rare Praise," March 15, 2006. Accessed at http://people-press.org/reports/ display.php3?ReportID=271, March 2006.

104 Tucker 2006.

105 Scheve and Slaughter 2001, 2004.

106 Kull 2004.

107 Watson Wyatt, "Offshoring Labor," August 5, 2004.

108 Inglehart, Nevitte, and Basanez 1996, 166.

109 Citrin et al. 1994; Rankin, 2001; O’Rourke and Sinnott 2002.

110 Pew Research Center, "Bush Approval Falls to 33\%," emphasis added.

111 Robert Reich, "Do we want the U.S. to be Rich or Japan Poor?” Wall Street Journal, June 18, 1990.

112 Herrmann, Tetlock, and Diascro 2001, 202.

113 Ibid., emphasis added.

114 Rousseau 2002, 411.

115 Holsti 2004; Wittkopf 1990; Feaver and Gelpi 2004.

116 Feaver and Gelpi 2004; see also Gelpi and Mueller 2006.

117 Druckman 2001.

118 Hiscox 2006.

119 Kull and Destler 1999, ch. 5. The robustness of this finding is open to question, however. See Kohut and Stokes 2006, 188-9.

120 Hurwitz and Peffley 1987; Page and Shapiro 1992; Nincic 1992; Holsti 1992; Jenkins-Smith and Herron 2005.

121 Chittick, Billingsley, and Travis 1995.

122 Boettcher and Cobb 2006; Brewer 2006.

123 I am grateful to Benjamin Fordham and Jonathan Caverley for their suggestions on this point. 
124 Todorov and Mandisodza 2004.

125 Powlick and Katz 1998, 34.

126 Page and Barabas 2000; Page and Bouton 2006.

127 Kennan 1984.

128 Unless otherwise noted, data in this paragraph comes from Bouton 2002 and Page and Barabas 2000.

129 Pew Research Center, "America's Place in the World II," October 1997. Accessed at http://people-press.org/ reports/pdf/102.pdf, April 2006.

130 Holsti 2004, 259.

131 Alvarez and Brehm 2002, ch. 9.

132 Schildkraut 2002.

133 Herrmann, Tetlock, and Diascro 2001, 200.

134 Rankin 2001, 362; Scheve and Slaughter 2001; Page and Bouton 2006.

135 Friedman 1999.

136 Huntington 1996, 57-58; Solingen 1998; Rosenau et al. 2005.

137 Herrmann and Keller 2004.

138 Jacobs and Page 2005, 113.

139 On journalists, see Tai and Chanfe 2002. On academics, see Maliniak et al. 2005, 2007. On businessmen, see PriceWaterhouseCoopers, "9th Annual Global CEO Survey,” January 2006.

140 Jacobs and Page 2004.

141 Kull and Destler 1999; Bouton 2004, ch. 5.

142 Peterson, Tierney, and Maliniak 2005; Maliniak et al. 2005, 2007.

143 Ibid. See also Walker and Morton 2005.

\section{References}

Almond, Gabriel. 1950. The American People and Foreign Policy. New York: Praeger.

. 1956. Public opinion and national security.

Public Opinion Quarterly 20 (2): 371-78.

Alvarez, Michael, and John Brehm. 2002. Hard Choices, Easy Answers: Values, Information and American Public Opinion. Princeton: Princeton University Press.

Art, Robert. 1998/99. Geopolitics Updated: The Strategy of Selective Engagement. International Security 23 (1): 79-113.

- 2003. A Grand Strategy for America. Ithaca: Cornell University Press.

Audley, John, and John Anker. 2004. Reconciling Trade and Poverty Reduction. Washington: German Marshall Fund of the United States.

- 2005. Perspectives on Trade and Poverty Reduction. Washington: German Marshall Fund of the United States.

Bacevich, Andrew. 2005. The New American Militarism. New York: Oxford University Press.

Bailey, T.A. 1948. The Man in the Street. New York: Macmillan.
Bauer, Raymond, Ithiel de Sola Pool, and Lewis Dexter. 1963. American Business and Public Policy. Chicago: Aldine.

Boettcher, William, and Michael Cobb. 2006. Echoes of Vietnam? Casualty framing and public perceptions of success and failure in Iraq. Journal of Conflict Resolution 50 (December): 831-54.

Bouton, Marshall, ed. 2002. Worldviews 2002: American Public Opinion \& Foreign Policy. Chicago: Chicago Council on Foreign Relations.

- 2004. Global Views 2004: American Public Opinion and Foreign Policy. Chicago: Chicago Council on Foreign Relations.

Brewer, Paul. 2004. Public trust in (or cynicism about) other nations across time. Political Behavior 26 (December): 317-40.

- 2006. National interest frames and public opinion about world affairs. Harvard International Journal of Press/Politics 11 (4): 89-102.

Brewer, Paul, et al. 2004. International trust and public opinion about world affairs. American Journal of Political Science 48 (1): 93-109.

Brewer, Paul, Sean Aday, and Kimberly Gross. 2005. Do Americans trust other nations? A panel study. Social Science Quarterly 86 (March): 36-51.

Brody, Richard. 1994. Crisis, war, and public opinion. In Taken by Storm: The Media, Public Opinion, and U.S. Foreign Policy in the GulfWar, ed. W. Lance Bennett and David Paletz. Chicago: University of Chicago Press.

Brooks, Stephen. 1997. Dueling realisms. International Organization 51 (3): 445-77.

Burbach, David. 1994. "Presidential Approval and the Use of Force." Defense and Arms Control Studies Program Working Paper, MIT, Cambridge, MA.

Buzan, Barry. 1984. Economic structure and international security. International Organization 38 (4): 597-624.

Carr, E.H. 1964 [1939]. The Twenty Years Crisis. New York: Harper and Row.

Chittick, William, Keith Billingsley, and Rick Travis. 1995. A three-dimensional model of American foreign policy beliefs. International Studies Quarterly 39 (3): 313-31.

Christensen, Thomas J., and Jack Snyder. 1990. Chain gangs and passed bucks: Predicting alliance patterns in multipolarity. International Organization 44 (2): 137-68.

Citrin, Jack, Ernst B. Haas, Christopher Muste, and Beth Reingold. 1994. Is American nationalism changing? Implications for foreign policy. International Studies Quarterly 38 (1): 1-31.

Converse, Philip. 1964. The nature of belief systems in mass publics. In Ideology and Discontent, ed. David Apter. New York: Free Press. 
Daalder, Ivo, and James Lindsey. 2007. Democracies of the world, unite! American Interest 11 (2): 34-44.

Destler, I.M. 1986. American Trade Politics. 3d ed. Washington: Institute for International Economics.

Doyle, Michael. 1983. Kant, liberal legacies, and foreign affairs, part 2. Philosophy and Public Affairs 12 (4): 323-53.

Drezner, Daniel. 2005. Trade Talk. American Interest 1 (2): 68-76.

—. 2007a. All Politics Is Global: Explaining International Regulatory Regimes. Princeton: Princeton University Press.

- 2007b. Lost in translation: The transatlantic divide over diplomacy. In Growing Apart: America and Europe in the 21st Century, ed. Jeffrey Kopstein and Sven Steinmo. Cambridge: Cambridge University Press.

Druckman, James. 2001. The implications of framing effects for citizen competence. Political Behavior 23 (3): $225-56$

Eichenberg, Richard. 2005. Victory has many friends: U.S. public opinion and the use of force, 1981-2005. International Security 30 (Summer): 140-77.

Elliott, Kimberly, and Richard Freeman. 2003. Can Labor Standards Improve under Globalization? Washington, DC: Institute for International Economics.

Everts, Philip, and Pierangelo Isernia. 2005. The war in Iraq. Public Opinion Quarterly 69 (Summer): 264-323.

Feaver, Peter, and Christopher Gelpi. 2004. Choosing Your Battles. Princeton: Princeton University Press. —. 2005/06. Success matters: Casualty sensitivity and the war in Iraq. International Security 30 (Winter): 7-46.

Friedberg, Aaron. 2000. In the Shadow of the Garrison State. Princeton: Princeton University Press.

Friedman, Thomas. 1999. The Lexis and the Olive Tree. New York: Farrar, Stauss Giroux.

Fukuyama, Francis. 2006. America at the Crossroads. New Haven: Yale University Press.

Gelpi, Christopher, and John Mueller. 2006. The costs of war. Foreign Affairs 85 (1): 139-44.

Gholz, Eugene, Daryl G. Press, and Harvey M. Sapolsky. 1997. Come home, America: The strategy of restraint in the face of temptation. International Security 21 (1): 5-48.

Gilboa, Eytan. 2005. The CNN effect. Political Comunication 22 (1): 27-44.

Gilpin, Robert. 1996. No one loves a political realist. Security Studies 5 (Spring): 3-28.

Gowa, Joanne. 1986. Anarchy, egoism, and third images. International Organization 40 (2): 167-86.

Grieco, Joseph. 1990. Cooperation Among Nations. Ithaca: Cornell University Press.

Hartz, Louis. 1955. The Liberal Tradition in America. New York: Harcourt Brace.
Herrmann, Richard, and Jonathan Keller. 2004. Beliefs, values, and strategic choice. Journal of Politics 66 (May): 557-80.

Herrmann, Richard, Philip Tetlock, and Matthew Diascro. 2001. How Americans think about trade. International Studies Quarterly 45 (1): 191-218.

Herrmann, Richard, Philip Tetlock, and Penny Visser. 1999. Mass public decisions to go to war: A cognitiveinteractionist framework. American Political Science Review 93 (3): 553-73.

Hirschman, Albert. 1977. The Passions and the Interests. Princeton: Princeton University Press.

Hiscox, Michael. 2006. Through a glass and darkly: Attitudes toward international trade and the curious effects of issue framing. International Organization 60 (July): 755-80.

Holsti, Ole. 1992. Public opinion and foreign policy: Challenging the Almond-Lippmann consensus. International Studies Quarterly 36 (4): 439-66.

-1996. Public opinion on human rights in American foreign policy. American Diplomacy 1 (1): http:// www.ciaonet.org/olj/ad/ad_v1_1/hoo01.html.

_. 2004. Public Opinion and American Foreign Policy. Rev. ed. Ann Arbor: University of Michigan Press.

Huntington, Samuel. 1957. The Soldier and the State. Cambridge: Belknap Press.

- 1996. The Clash of Civilizations and the Remaking of World Order. New York: Simon and Schuster.

Hurwitz, Jon, and Mark Peffley. 1987. How are foreign policy attitudes structured? American Political Science Review 81 (4): 1100-20.

Ikenberry, John, and Anne-Marie Slaughter. 2006. Forging a World of Liberty under Law: U.S. National Security in the 21st Century. Princeton: Princeton Project for National Security.

Inglehart, Ronald, Neil Nevitte, and Miguel Basanez. 1996. The North American Trajectory. New York: Walter de Gruyter.

Jacobs, Lawrence, and Benjamin Page. 2004. "The Media and the Foreign Policy Establishment." Presented at the Midwestern Political Science Association, Chicago, IL, April 15-18.

- 2005. Who influences U.S. foreign policy? American Political Science Review 99 (1): 107-23.

Jackson, Patrick T., and Stuart Kaufman. 2007. Security scholars for a sensible foreign policy: A study in Weberian activism. Perspectives on Politics 5 (1): 95-103.

Jenkins-Smith, Hank, and Kerry Herron. 2005. United States public responses to terrorism. Review of Policy Research 22 (6): 599-623.

Jentleson, Bruce. 1992. The pretty prudent public: Post-Vietnam American opinion and the use of military force. International Studies Quarterly 36 (1): 49-74. 
Jentleson, Bruce, and Rebecca Britton. 1998. Still pretty prudent: Post-Cold War American public opinion on the use of military force. Journal of Conflict Resolution 42 (4): 395-417.

Kagan, Robert. 2006. Dangerous Nation. New York: Knopf.

Kagan, Robert, and William Kristol. 2000. Present Dangers. San Francisco: Encounter.

Kaufmann, Chaim. 2004. Threat inflation and the failure of the marketplace of ideas. International Security 29 (Summer): 5-48.

Kennan, George. 1984. American Diplomacy, expanded edition. Chicago: University of Chicago Press.

Key, V.O. 1961. Public Opinion and American Democracy. New York: Knopf.

Kissinger, Henry. 1960. The Necessity for Choice. New York: Praeger.

- 1994. Diplomacy. New York: Simon \& Schuster.

Klarevas, Louis. 2002. The "essential domino" of military operations: American public opinion and the use of force. International Studies Perspectives 3 (4): 417-37.

Kohut, Andrew, and Bruce Stokes. 2006. America against the World. New York: Times Books.

Krasner, Stephen D. 1978. Defending the National Interest. Princeton: Princeton University Press.

. 1991. Global communications and national power: Life on the Pareto frontier. World Politics 43 (3): 336-66.

Kull, Steven. 2004. "Americans on Globalization, Trade and Farm Subsidies." Program on International Policy Attitudes, Washington, DC.

Kull, Stephen, and I.M. Destler. 1999. Misreading the Public. Washington, DC: Brookings Institution.

Larson, Eric. 1996. Casualties and Consensus: The Historical Role of Casualties in Domestic Support for U.S. Military Operations. Santa Monica: RAND.

Layne, Christopher. 1997. From preponderance to offshore balancing. International Security 22 (1): 86-124.

- 2006. The Peace of Illusions: American Grand Strategy from 1940 to the Present. Ithaca: Cornell University Press.

Legro, Jeffrey, and Andrew Moravcsik. 1999. Is anyone still a realist? International Security 24 (3): 55-106.

Lepgold, Joseph, and Timothy McKeown. 1995. Is American foreign policy exceptional? Political Science Quarterly 110 (3): 369-84.

Lieven, Anatol, and John Hulsman. 2006. Ethical Realism. New York: Pantheon.

Lind, Michael. 2006. The American Way of Strategy. New York: Oxford University Press.

Lippmann, Walter. 1955. The Public Philosophy. Boston: Little, Brown.

Lipset, Seymour Martin. 1996. American Exceptionalism: A Double-Edged Sword. New York: W.W. Norton.
Maliniak, Daniel, Amy Oakes, Susan Peterson and Michael Tierney. 2005. Inside the ivory tower. Foreign Policy 151 (November/December ): 58-64.

- 2007. The view from the ivory tower. Program on the theory and practice of international relations. Foreign Policy 159 (March/April): 62-9.

Mandelbaum, Michael. 1996. Foreign policy as social work. Foreign Affairs 75 (January/February): 16-32.

McDougall, Walter. 1997. Promised Land, Crusader State: The American Encounter with the World Since 1776. New York: Mariner Books.

McFarland, Sam, and Melissa Matthews. 2005a. Who cares about human rights? Political Psychology 26 (June): 365-85.

- 2005b. Do Americans care about human rights? Journal of Human Rights 4 (3): 305-20.

Mead, Walter Russell. 2002. Special Providence. New York: Alfred A. Knopf.

Mearsheimer, John. 2001. The Tragedy of Great Power Politics. New York: W.W. Norton.

Mearsheimer, John, and Stephen Walt. 2003. An unnecessary war. Foreign Policy 134: 50-9.

- 2006. The Israel lobby and U.S. foreign policy. Middle East Policy 13 (3): 29-87.

— 2007. The Israel Lobby and U.S. Foreign Policy.

New York: Farrar, Straus, and Giroux.

Mermin, Jonathan. 1997. Television news and American intervention in Somalia: The myth of a media-driven foreign policy. Political Science Quarterly 112 (3): 385-403.

Monten, Jonathan. 2005. The roots of the Bush doctrine. International Security 29 (Spring): 112-56.

Morgenthau, Hans, and Kenneth Thompson. 1985. Politics among Nations, 6th ed. New York: McGraw-Hill.

Mueller, John. 1973. War, Presidents, and Public Opinion. New York: Wiley.

2005. The Iraq syndrome. Foreign Affairs 84 (6): 45-54.

Nau, Henry. 2002. At Home Abroad: Identity and Power in American Foreign Policy. Ithaca: Cornell University Press.

Nincic, Miroslav. 1992. A sensible public: New perspectives on popular opinion and foreign policy. Journal of Conflict Resolution 36 (4): 772-89.

- 1994. Democracy and Foreign Policy: The Fallacy of Political Realism. New York: Columbia University Press.

Oneal, John, Brad Lian, and James Joyner. 1996. Are the American people "pretty prudent"? Public responses to U.S. uses of force, 1950-1988. International Studies Quarterly 40 (2): 261-79.

O'Rourke, Kevin, and Richard Sinnott. 2002. The determinants of individual trade policy preferences. In Brookings Trade Forum, ed. Susan Collins and Dani Rodrik. Washington DC: Brookings Institution. 
Page, Benjamin, and Jason Barabas. 2000. Foreign policy gaps between citizens and leaders. International Studies Quarterly 44 (3): 339-64.

Page, Benjamin, with Marshall Bouton. 2006. The Foreign Policy Disconnect. Chicago: University of Chicago Press.

Page, Benjamin, and Robert Shapiro. 1992. The Rational Public: Fifty Years of Trends in Americans' Policy Preferences. Chicago: University of Chicago Press.

Peterson, Susan, Michael Tierney, and Daniel Maliniak. 2005. "Teaching and Research Practices, Views on the Discipline, and Policy Attitudes of International Relations Faculty at U.S. Colleges and Universities." Williamsburg, VA: Program on the Theory and Practice of International Relations, The Wendy and Emery Reves Center for International Studies College of William \& Mary.

Powlick, Philip J., and Andrew Z. Katz. 1998. Defining the American public opinion/foreign policy nexus. Mershon International Studies Review 42 (May): 29-61.

Rankin, David. 2001. Identities, interests, and imports. Political Behavior 24 (4): 351-76.

Reiter, Dan, and Allan C. Stam. 2002. Democracies at War. Princeton: Princeton University Press.

Rielly, John E., ed. 1999. American Public Opinion and U.S. Foreign Policy 1999. Chicago: Chicago Council on Foreign Relations.

Robinson, Piers. 1999. The CNN effect: Can the news media drive foreign policy? Review of International Studies 25 (2): 301-09.

Rose, Gideon. 1998. Neoclassical realism and theories of foreign policy. World Politics 51 (1): 144-72.

Rosenau, James. 1961. Public Opinion and Foreign Policy. New York: Random House.

Rosenau, James, David Earnest, Yale Ferguson, and Ole Holsti. 2005. On the Cutting Edge of Globalization: An Inquiry Into American Elites. New York: Rowman and Littlefield.

Rousseau, David. 2002. Motivations for choice: The salience of relative gains in international politics. Journal of Conflict Resolution 46 (3): 394-426.

Ruggie, John Gerard. 1997. The past as prologue? Interests, identity, and American foreign policy. International Security 21 (2): 89-125.

Scheve, Kenneth F., and Matthew Slaughter. 2001. Globalization and the Perceptions of American Workers. Washington: Institute for International Economics.
2004. Economic Insecurity and the Globalization of Production. American Journal of Political Science 48 (4): 662-74.

Schildkraut, Deborah J. 2002. The more things change ... American identity and mass and elite responses to 9/11. Political Psychology 23 (3): 511-35.

Schweller, Randall. 2004. Unanswered threats: A neoclassical realist theory of underbalancing. International Security 29 (Fall): 159-201.

Solingen, Etel. 1998. Regional Orders at Century's Dawn: Global and Domestic Influences on Grand Strategy. Princeton: Princeton University Press.

Snyder, Jack. 1991. Myths of Empire. Ithaca: Cornell University Press.

Strobel, Warren. 1997. Late-Breaking Foreign Policy. Washington: U.S. Institute of Peace.

Tai, Zixue, and Tsan-Kuo Chanfe. 2002. The global news and the pictures in their heads. Gazette: The International Journal for Communications Studies 64 (3): 251-65.

Todorov, Alexander, and Anesu Mandisodza. 2004. Public opinion on foreign policy. Public Opinion Quarterly 68 (Fall): 323-48.

Tucker, Todd. 2006. "Election 2006: No to staying the course on trade." Public Citizen. Washington DC. Accessed at http://www.citizen.org/documents/ Election2006.pdf.

Walker, Thomas, and Jeffrey Morton. 2005. Reassessing the "power of power politics" thesis: Is realism still dominant? International Studies Review 7 (June): 341-56.

Walt, Stephen M. 2005. Taming American Power. New York: W.W. Norton, 2005.

Waltz, Kenneth. 1967. Foreign Policy and Democratic Politics. Boston: Little, Brown.

- 1979. Theory of International Politics. New York: McGraw Hill.

Western, Jon. 2005. The war over Iraq: Selling war to the American public. Security Studies 14 (1): 106-39.

Wittkopf, Eugene. 1990. Faces of Internationalism: Public Opinion and American Foreign Policy. Durham: Duke University Press.

Woods, Kevin, James Lacey, and Williamson Murray. 2006. Saddam's delusions: The view from the inside. Foreign Affairs 85 (3): 2-26.

Zakaria, Fareed. 1998. From Wealth to Power. Princeton: Princeton University Press. 